\title{
Evaluating Ruang Guru Application From Instructional and Financial Points of View
}

\author{
Agus Rahman* \\ Postgraduate English Department \\ Universitas Mataram \\ Mataram Indonesia \\ agusrahmanlearn@gmail.com
}

\author{
Kamaludin Yusra \\ English Department \\ Universitas Mataram \\ Mataram Indonesia \\ kamaludin@unram.ac.id
}

\author{
Arifuddin Arifuddin \\ English Department \\ Universitas Mataram \\ Mataram Indonesia \\ arifuddin@unram.ac.id
}

\begin{abstract}
This paper evaluates the use of English materials on a recently booming online learning platform in Indonesia named Ruang Guru. It analyzed the contents of the materials for instructional purposes and evaluates whether they are worth purchasing by English learners from financial points of view. The study is qualitative in nature as it is a descriptive content analysis. The data were collected by downloading English learning materials and videos in the Ruang Guru application provided by the schools for their students. The data were analyzed based on the criteria proposed by Minister of Education and Culture in Indonesia in terms of standard of goals, contents, processes and assessments set up in the national curriculum of 2013. The study found that; (a) most of the language topics presented by Ruang Guru on the materials and videos were in line with the prescribed topics on the government addressed syllabus, curriculum and other documents, (b) the topics presented are based on national curriculum 2013, and (c) the payment charged for subscription on this online learning platform is fairly considerable for a number of considerations.
\end{abstract}

Keywords - learning application, IT-based materials, Ruang Guru, content analysis

\section{INTRODUCTION}

Teachers have played essential roles in classroom for a long time. The presence of teachers is an absolute requirement for learning activity to take place since they are the center of genuine sources of knowledge. Students are considered as empty glasses to receive whatever knowledge teachers are willing to pour into them. It turns students into passive learners as there is no chance to accommodate students' capacity to develop their own learning potential. In fact, students are unique learners who have capabilities to actively engage in classroom or even to provide learning materials and as the center of learning itself as well.

Fortunately, this traditional approach of teaching has gradually changed especially in the recent remarkable era of revolution industry 4.0 where this old-fashioned classroom environment is hardly to stand on its feet. The prominent role of teachers is now shifted since students are highly encouraged to actively participate in learning activity. Teachers become learning facilitator and students are expected to be independent learners. Both students and teachers are co-learners in a way that they learn together in classroom [1]. Thus, the current curriculum, K-13, implemented in Indonesia is based on this classroom environment perspective.

This current view of teaching learning environment challenges school administrator, education practitioner, government as well as teachers to equip students with variety and adequate resources to construct their learning independence. In the case of English language teaching and learning, a readily access to printed resources such as textbooks, articles and many others is inevitable. But unfortunately, the accessibility to these printed resources is not completely satisfying in terms of supply and newly updated version. However, as the rapid growth of internet, relying on such printed resources might be no longer needed since a handy access to abundant of updated materials such as application is widely provided. This technological improvement effects how education work and increase teaching learning productivity [2]

Clements and Sarama clearly stated that technological based material is practical for learners [3]. It is due to, according to Bull and Ma, uncounted numbers of resources for language learners that technology can offer [4]. More convincingly, Tomlinson and Gençlter said that materials taken from the internet can make students want to learn more [5], [6]. Likewise, Pourhosein Gilakjani and Sabouri stated that via technology, students are in control of their progress in learning because they can get any kind of information [7]. Thus, technology assisted learning, according to Ahmadi "is an essential part of the teachers' profession through which they can use to facilitate learners' learning" [8].

Despite of having important contribution, the content it provides should reflect the national curriculum standard. Thus, an analysis of its contents is inevitable to verify its relevance. Unlike printed materials like textbook, the evaluation of learning application is yet to be done, or it is rarely conducted. Besides, this online application charges larger amount of money for the materials it offers compared to textbook. This subscription payment should work as an assurance for better content presentation otherwise there is no mean of labelling a higher price tag on it. Therefore, it is crucial for this paper to analyze this online learning application for number of reasons. Firstly, it is widely used as resources for independent learning. Secondly, it is expected to highly contribute to the implementation of government curriculum and syllabus. Thirdly, the payment charged should be a signal for a better materials presentation. The object of analysis is Ruang Guru application. It is due to Ruang Guru outrageously claiming that its contents are based on curriculum K-13. It is also a payable application and is recently a booming online learning platform in Indonesia. 
The objectives of this paper are to evaluate English materials for secondary school in Ruang Guru based on the standard criteria proposed by Minister of Education and Culture in Indonesia in terms of standard of goals, contents, processes and assessments set up in the national curriculum of 2013 and whether those materials are worth buying for English learners in terms of financial perspective.

\section{METHOD}

This study is qualitative as its purpose is to check the quality of online learning application based on standard criteria proposed by Indonesian Government. It used content analysis method to analyze qualitative data and describe the data which is based on evaluation. Data were collected through downloading English materials and videos for secondary school provided by Ruang Guru application on its portal. The data were extracted and then were analyzed based on the criteria proposed by Minister of Education and Culture in Indonesia in terms of standard of goals, contents, processes and assessments set up in the national curriculum of 2013 .

\section{RESULTS AND DISCUSSION}

The focus of the study is on the Ruang Guru application. In order to do so, teaching-learning expected in the 2013 curriculum should be clarified first.

\section{A. The nature of English teaching and learning on curriculum 2013}

Learning resources are highly expected to be in harmony with the standardized syllabus in curriculum 2013. The emphasis is given on the material content, which is an activity based, that drives learners to actively engage in classroom through project and task-based learning. Students are encouraged to independently gain knowledge so that they can use it in real life situation.

The goal of learning English, in general, is to develop and maximize student's communicative competence through using variety of written and spoken texts in real life situation. Text functions facilitatively for students to use factual, conceptual, metacognitive and procedural knowledge. Students are expected to have communicative skills by using English effectively in social context based on their interest and talent to solve problems in a given situation. They can understand the underlying idea of text and compose their own texts through speaking, listening, reading and writing in different topic. Also, students develop their processing and reasoning skills as well as using English independently either in abstract or concrete thinking based on appropriate language structure.

In other words, language learning is primarily to benefit students in every day real life situation in various social contexts by using different type of texts. Text itself is a means of communication and thinking. It is used to express meaning and purpose of doing certain thing in social context. The purpose of communication is to negotiate factual, procedural and conceptual information among participants according to contextual setting. Thus, the materials presented are genre-based. Genre-based approach is text-based learning which views language learning as a social activity to express meaning, interpreting and organizing reality as well as to construct students' knowledge and skill to actively participate in social context using spoken and written text.

To have benefit from learning, students work collaboratively with teachers, classmates and others through interaction which involves language. Teacher's role is to guide learners in order to gradually perform independently without any contribution of the teacher. The learning process consists of five stages; building the context, modeling and deconstructing the text, joint construction of the text, independent construction of the text and linking related text [9]. Learning process involves observing, questioning, collecting information, associating and communicating. Students are expected to take initiation and work collaboratively in a group under close supervision of the teachers. Learning process is to habituate students with the text structure so that they can produce utterance fluently in unconscious way.

As a text-based learning, the content that should be considered when designing materials includes four compulsory texts in curriculum 2013 syllabus, they are: interpersonal, transactional, functional and special functional texts. Interpersonal text is a communicative text that is used to interact and socialize with others. Transactional text is type of text that is used to get something from others. While functional text deals with information which occur in daily life interaction as it is associated with particular purpose or function like announcement, advertisement, invitation, letter, and so forth [10].

The last point about curriculum 2013 is how the assessment is conducted. It emphasizes on questions that provoke student critical thinking not merely based on memorization. It is an ongoing assessment to measure students' thinking skill in using English both spoken and written according to context and social function [10].

\section{B. English material on Ruang Guru and its compatibility to curriculum 2013}

Ruang Guru is basically a technology-based business company which focuses on providing educational services. It was founded by Belva Devara and Iman Usman in 2014. It has more than 6 million users, 150.000 teachers and 100 subjects of study mostly for elementary and secondary school students. A massive advertising on most of national televisions has made it gain more popularity to attract new users. It also works with local government to provide high quality education through a program called Study Management System. It has got many awards from International organizations like the Atlantis Foundation, Bubu Awards but also from government body like Department of Foreign Affairs and Trade of Australian Government [11]. More details about Ruang Guru can be found on its web address https://ruangguru.com.

The focus of this paper is to evaluate its content of English materials in terms of compatibility and congruency to standard of goals, content, process and assessment of national curriculum 2013

\section{1) Content, Process and Assessment}

In order to define whether English materials on this application meet the standard of goals of national curriculum or not, the content of this material along with process and assessment need to be analyzed at the initial stage. As the 
standard content of curriculum 2013 is text-based, it is advisable to examine the availability of the text on Ruang Guru Application. There are four type of texts as stated above; interpersonal text, transactional text, functional text and special functional text.

Interpersonal text on Ruang Guru as presented in table 1 shows that almost all the required texts in curriculum 2013 are available, however, there are no topics expressing giving order, invitation and pray.

TABLE I. INTERPERSONAL TEXTS IN RUANG GURU

\begin{tabular}{|c|c|c|}
\hline No & $\begin{array}{l}\text { Interpersonal text in } \\
\text { curriculum } 2013\end{array}$ & $\begin{array}{c}\text { Interpersonal text in Ruang } \\
\text { Guru }\end{array}$ \\
\hline 1 & $\begin{array}{l}\text { Expressing congratulation } \\
\text { Expressing compliment }\end{array}$ & $\begin{array}{l}\text { Expression of congratulation on } \\
\text { special occasion and special } \\
\text { achievement } \\
\text { Expression of asking for } \\
\text { compliments and expression of } \\
\text { compliments }\end{array}$ \\
\hline 2 & $\begin{array}{l}\text { Greeting } \\
\text { Farewell } \\
\text { Thanking and } \\
\text { Asking for apologize along } \\
\text { with their responses }\end{array}$ & $\begin{array}{l}\text { Expression of greeting } \\
\text { Expression of parting and } \\
\text { addressing } \\
\text { Expression of thanking someone } \\
\text { and response to someone thanking } \\
\text { you } \\
\text { Expression of apologizing and } \\
\text { responding to } \\
\text { Expression of apologizing }\end{array}$ \\
\hline 3 & $\begin{array}{l}\text { Asking for attention } \\
\text { Checking understanding } \\
\text { Asking and giving opinion }\end{array}$ & $\begin{array}{l}\text { Asking for attention } \\
\text { Expression of checking } \\
\text { understanding } \\
\text { Showing lack of understanding } \\
\text { Showing understanding } \\
\text { Asking for opinion } \\
\text { Giving opinion }\end{array}$ \\
\hline 4 & $\begin{array}{l}\text { Giving order } \\
\text { Invitation } \\
\text { Asking for permission }\end{array}$ & $\begin{array}{l}\text { Expression of asking for } \\
\text { permission } \\
\text { Granting permission } \\
\text { Rejecting permission } \\
\text { There is no giving order and } \\
\text { invitation }\end{array}$ \\
\hline 5 & $\begin{array}{l}\text { Expressing hope } \\
\text { Expressing pray and } \\
\text { Congratulate other along } \\
\text { with their responses } \\
\text { according to the context }\end{array}$ & $\begin{array}{l}\text { Expression of congratulation } \\
\text { Expression of celebration } \\
\text { Expression of wish and hope } \\
\text { There is no expression of pray }\end{array}$ \\
\hline
\end{tabular}

Unlike interpersonal text, some compulsory transactional texts are not well presented. Table 2 below show that there are nine topics which are missing indicated by using (-) sign and italic sentences.

TABLE II. TRANSACTIONAL TEXTS IN RUANG GURU

\begin{tabular}{|l|l|l|}
\hline No & $\begin{array}{c}\text { Transactional text in } \\
\text { curriculum 2013 }\end{array}$ & \multicolumn{1}{c|}{$\begin{array}{c}\text { Transactional text in Ruang } \\
\text { Guru }\end{array}$} \\
\hline 1 & $\begin{array}{l}\text { Expressing identity using } \\
\text { pronoun, subjective, } \\
\text { objective, possessive }\end{array}$ & $\begin{array}{l}\text { Subject pronoun } \\
\text { Object pronoun } \\
\text { Possessive adjective }\end{array}$ \\
\hline 2 & $\begin{array}{l}\text { Conditional an past } \\
\text { Order and suggestion } \\
\text { using if, imperative, can, } \\
\text { should }\end{array}$ & $\begin{array}{l}\text { Future, present and } \\
\text { conditional } \\
\text { There is no Expression of } \\
\text { order, suggestion, imperative, } \\
\text { modal can should }\end{array}$ \\
\hline 3 & $\begin{array}{l}\text { Offering service May I } \\
\text { help you?, What can I do } \\
\text { for you? What if ...? }\end{array}$ & $\begin{array}{l}\text { Asking for help } \\
\text { Offering help } \\
\text { Response to someone offering } \\
\text { help }\end{array}$ \\
\hline 4 & Passive voice & $\begin{array}{l}\text { Simple tense passive form } \\
\text { Perfect tense passive form }\end{array}$ \\
\hline
\end{tabular}

\begin{tabular}{|c|c|c|}
\hline No & $\begin{array}{l}\text { Transactional text in } \\
\text { curriculum } 2013\end{array}$ & $\begin{array}{c}\text { Transactional text in Ruang } \\
\text { Guru }\end{array}$ \\
\hline 5 & $\begin{array}{l}\text { Cause and effect using } \\
\text { because of ..., due to ..., } \\
\text { thanks to ... }\end{array}$ & - \\
\hline 6 & $\begin{array}{l}\text { Giving opinion and idea } \\
\text { using I think, I suppose, in } \\
\text { my opinion }\end{array}$ & $\begin{array}{l}\text { Asking for opinion } \\
\text { Expression of giving opinion }\end{array}$ \\
\hline 7 & $\begin{array}{l}\text { Expresing ability using } \\
\text { modal can and will }\end{array}$ & $\begin{array}{l}\text { Showing ability using can and } \\
\text { could }\end{array}$ \\
\hline 8 & $\begin{array}{l}\text { Advice using modal } \\
\text { should dan can }\end{array}$ & $\begin{array}{l}\text { Expression of asking advice } \\
\text { Expression of giving advice }\end{array}$ \\
\hline 9 & Degree of comparison & Comparative and superlative \\
\hline 10 & $\begin{array}{l}\text { Existence using there } \\
\text { is/are }\end{array}$ & - \\
\hline 11 & $\begin{array}{l}\text { Obligation } \\
\text { Prohibition and appealing } \\
\text { using modal must and } \\
\text { should }\end{array}$ & $\begin{array}{l}\text { Showing obligation-must \& } \\
\text { have to } \\
\text { Showing prohibition using } \\
\text { modal and imperative } \\
\text { Showing no obligation } \\
\end{array}$ \\
\hline 12 & Be and adjective & - \\
\hline 13 & $\begin{array}{l}\text { Simple past tense vs } \\
\text { present perfect tense }\end{array}$ & $\begin{array}{l}\text { Simple past tense } \\
\text { Present perfect tense }\end{array}$ \\
\hline 14 & $\begin{array}{l}\text { Declarative } \\
\text { interrogative } \\
\text { Simple present tense } \\
\text { Present continuous tense } \\
\text { Past continuous } \\
\text { Will + continuous }\end{array}$ & $\begin{array}{l}\text { Introduction to simple present } \\
\text { tense } \\
\text { Present continuous tense } \\
\text { Future continuous } \\
\text { Past continuous } \\
\text { There is no declarative \& } \\
\text { interrogative }\end{array}$ \\
\hline 15 & $\begin{array}{l}\text { Article an and the, plural } \\
\text { and singular }\end{array}$ & - \\
\hline 16 & $\begin{array}{l}\text { Expressing purposes using } \\
\text { will, be going to, and } \\
\text { expressing agreement, } \\
\text { disagreement }\end{array}$ & - \\
\hline 17 & $\begin{array}{l}\text { Action/activities using be } \\
\text { going to, would like to }\end{array}$ & - \\
\hline 18 & $\begin{array}{l}\text { Name of the days, months, } \\
\text { year, time, ordinal and } \\
\text { cardinal number }\end{array}$ & $\begin{array}{l}\text { Introduction to time } \\
\text { Introduction to date } \\
\text { No name of the days, months, } \\
\text { ordinal and cardinal number }\end{array}$ \\
\hline
\end{tabular}

Table 3 and 4 show that almost all functional texts are available in Ruang Guru except two topics which are missing.

TABLE III. SPECIAL FUNCTIONAL TEXTS IN RUANG GURU

\begin{tabular}{|c|c|c|}
\hline No & $\begin{array}{c}\text { Special functional text in } \\
\text { curriculum } 2013\end{array}$ & $\begin{array}{c}\text { Special functional text in } \\
\text { Ruang Guru }\end{array}$ \\
\hline 1 & $\begin{array}{l}\text { Announcement related to } \\
\text { school activity }\end{array}$ & How to make announcement \\
\hline 2 & $\begin{array}{llr}\text { Manual use } & \text { of } \\
\text { technological } & \text { devices and } \\
\text { tips } & \end{array}$ & $\begin{array}{l}\text { How to make procedural text } \\
\text { Aspect of procedural text }\end{array}$ \\
\hline 3 & $\begin{array}{l}\text { Text caption of picture, } \\
\text { graph, table, picture }\end{array}$ & $\begin{array}{l}\text { Photo and image caption } \\
\text { Table and diagram } \\
\text { Chart }\end{array}$ \\
\hline 4 & Application letter & $\begin{array}{l}\text { How to make resume } \\
\text { How to make over letter } \\
\text { How to make CV }\end{array}$ \\
\hline 5 & Personal letter & $\begin{array}{l}\text { How to make a personal letter } \\
\text { Expressions in personal letter }\end{array}$ \\
\hline 6 & $\begin{array}{l}\text { Advertisement of goods } \\
\text { and services }\end{array}$ & $\begin{array}{l}\text { How to make advertisement } \\
\text { Structure and organization of } \\
\text { advertisement }\end{array}$ \\
\hline 7 & $\begin{array}{l}\text { Label related to food, } \\
\text { drink and medicine }\end{array}$ & $\begin{array}{l}\text { Label and schedule } \\
\text { Medicine prescription }\end{array}$ \\
\hline
\end{tabular}




\begin{tabular}{|l|l|l|}
\hline No & $\begin{array}{l}\text { Special functional text in } \\
\text { curriculum 2013 }\end{array}$ & \multicolumn{1}{|c|}{$\begin{array}{c}\text { Special functional text in } \\
\text { Ruang Guru }\end{array}$} \\
\hline 8 & $\begin{array}{l}\text { Short message and notice } \\
\text { related to school activity }\end{array}$ & $\begin{array}{l}\text { How to make an announcement } \\
\text { Events and activities }\end{array}$ \\
\hline 9 & $\begin{array}{l}\text { Official invitation related } \\
\text { to giving and asking } \\
\text { information about } \\
\text { school/office activities }\end{array}$ & - \\
\hline 10 & $\begin{array}{l}\text { Song lyric related to } \\
\text { teenager }\end{array}$ & $\begin{array}{l}\text { Learning from song } \\
\text { seasonal and special events }\end{array}$ \\
\hline 11 & Greeting card & \multicolumn{2}{|l}{} \\
\hline
\end{tabular}

TABLE IV. SPECIAL FUNCTIONAL TEXTS IN RUANG GURU

\begin{tabular}{|c|c|c|}
\hline No & $\begin{array}{l}\text { Functional text in } \\
\text { curriculum } 2013\end{array}$ & $\begin{array}{c}\text { Functional text in Ruang } \\
\text { Guru }\end{array}$ \\
\hline 1 & $\begin{array}{l}\text { Descriptive text related to } \\
\text { tourist destination, historic } \\
\text { building, person, animal } \\
\text { and thing }\end{array}$ & Aspects of descriptive text \\
\hline 2 & $\begin{array}{l}\text { Food and drink receipes } \\
\text { and manuals }\end{array}$ & - \\
\hline 3 & $\begin{array}{l}\text { News item in newsaper, } \\
\text { radio and television }\end{array}$ & Aspects of news item \\
\hline 4 & $\begin{array}{l}\text { Procedure text in form of } \\
\text { manual book }\end{array}$ & Aspects of procedure text \\
\hline 5 & $\begin{array}{l}\text { Explanation about nature } \\
\text { or social related to other } \\
\text { subjects and information } \\
\text { report }\end{array}$ & Aspects of explanation \\
\hline 6 & $\begin{array}{l}\text { Analitycal expository } \\
\text { about actual issues }\end{array}$ & $\begin{array}{l}\text { Analytical exposition text } \\
\text { Hortatory exposition text }\end{array}$ \\
\hline 7 & $\begin{array}{l}\text { Narrative text related to } \\
\text { folcklore, fairytales, fable }\end{array}$ & Aspects of narrative text \\
\hline 8 & $\begin{array}{l}\text { Recount text related to } \\
\text { historic events, personal } \\
\text { experience }\end{array}$ & Aspects of recount text \\
\hline
\end{tabular}

The tabulated data on table 1 to table 4 indicate that the topics or text in Ruang Guru are mostly in line with the prescribed content on the syllabus. Although there are topics that are missing, it does not radically downgrade the quality of this application. It holds true since not all resources can provide materials completely to the users even for high-rated textbook. Hence, teachers may use supplementary resources to cover the missing parts instead of relying on one particular resource. The fundamental issue is that the content of the resources is the reflection of the syllabus in order to achieve the goal of national education.

In terms of the process, students are initially introduced with the basic concept of the text including the setting, the purpose of the text in social context. Most of the videos outline the content as well as the context through audiovisual exposure in form of dialogue or role play in a given situation. Secondly, structural patterns and language features are extracted from the dialogue and then being highlighted on the screen while the tutor explained the function of those patterns and how to use them in social context. Thirdly, students are given chance to work independently by listening and watching the text again and at the end of the session students are given reading materials related to the topic of the text. These processes are equivalent to three out of five stages of learning process proposed in genre-based approach. They are; building the context, modeling and deconstructing the text and independent construction of the text which are parallel to the three processes above respectively. While for the other two stages, joint construction of the text and linking related text, appear in classroom setting.

For the assessment itself, students are given questions right after the topic has been presented. The assessment is in form multiple choices, fill-in-blank dialogue, exception, truefalse and finding information on the dialogue. This kind of assessment is to measure students' understanding of the topic while at the same time to encourage students to compose their own texts. It is an ongoing assessment that measures the progress of students' learning process. Hence, it is in line with the curriculum 2013 as the assessment is emphasized on the learning process of the students not only the end product of students' work and also on building critical thinking of the students.

\section{2) Standard of Goals}

As stated earlier, to say that Ruang Guru meets the goals of curriculum 2103 is much rely on the quality of content, process and assessment of the materials according to the standard syllabus. Also as already explained that the goal of curriculum 2013 in English language teaching is to enable students to use the language in social context according to their roles and need in solving their problems. The curriculum was designed based on this perspective through genre-based approach. Therefore, as long as the learning resources including Ruang Guru are in line with the syllabus, it can be said that they meet the standard of goals of national curriculum 2103. Ruang Guru fulfilled most of the standard stated on the syllabus in terms of content, process and assessment

\section{3) Financial Point of View}

As a business company, Ruang Guru levies amount of money for its educational services. The nominal paid for subscription depends on the services, materials and period of subscription whether two years, one year, one semester or for one month only. The lowest charge is IDR. 250.000, - for one month and IDR.1.450.000, - for the longest period of 2 years subscription. However, this number is not fixed as it may change anytime according to company's policy.

This paper considers the content analysis of materials as the primary criteria, along with the above-mentioned criteria, to see whether the money charged is worth or not. As previously discussed, materials are considered applicable only when the content, process, assessment meet the standard curriculum goals. Ruang Guru is mostly in line with those criteria. Hence, like printed materials such as textbook, this online application is also worth buying. It can, roughly speaking, stand by itself to facilitate learners while textbook, on the other hand, needs teachers in order to play in classroom. Moreover, it is more attractive in terms of visual display and audio along with its accessibility. The videos are downloadable, so it is durable materials, like textbook, to use whenever needed

\section{CONCLUSION}

The analysis of this kind of materials is still rare. In fact, online learning application is great in number and it becomes trend in the current technological era. It is not impossible that the presence of teacher in classroom can be shifted as the 
emerging of online learning is now inevitable around the globe in which students do not need to attend the class physically as they can have virtual classroom instead. The need of this online application must be supported with critical analysis of its content so that users can benefit from the reliable online application which is based on national standard. It can be used interchangeably with the printed ones regarding the contents they share, however, there is no guarantee that it can replace the use of textbook in classroom.

Finally, its development is unstoppable, but it cannot run uncontrolled. Critical analysis of this learning portal is crucial to ensure that the materials it offers are suitable and reliable based on the prescribed government standard. Ruang Guru, as one of online learning platforms, is considered reliable as most of the criteria on the curriculum 2013 standard syllabus have been met in terms of content, process, assessment as well as the goals. Secondly, the required payment for subscription is also fairly considerable for its durability, attractiveness and accessibility.

\section{REFERENCES}

[1] G. M. Jacobs and W. A. Renandya, "Student-centred learning in ELT," in English language teaching today, Springer, 2016, pp. 13-23.

[2] S. D. Shyamlee and M. Phil, "Use of technology in English language teaching and learning: An analysis," in International Conference on Language, Medias and Culture, 2012, vol. 33, no. 1, pp. 150-156.

[3] D. H. Clements and J. Sarama, "Strip Mining for Gold: Research and Policy in Educational Technology-A Response to," Educ. Technol. Rev., vol. 11, no. 1, p. n1, 2003.

[4] S. Bull and Y. Ma, "Raising learner awareness of language learning strategies in situations of limited resources," Interact. Learn. Environ., vol. 9, no. 2, pp. 171-200, 2001.

[5] B. Tomlinson, Materials development in language teaching. Cambridge University Press, 2011.

[6] B. G. İlter, "How does technology affect language learning process at an early age," Procedia-Social Behav. Sci., vol. 199, pp. 311-316, 2015.

[7] A. P. Gilakjani and N. B. Sabouri, "Role of Iranian EFL Teachers about Using" Pronunciation Power Software" in the Instruction of English Pronunciation.," English Lang. Teach., vol. 7, no. 1, pp. 139-148, 2014.

[8] D. Ahmadi and M. Reza, "The use of technology in English language learning: A literature review," Int. J. Res. English Educ., vol. 3, no. 2, pp. 115-125, 2018.

[9] H. Nugroho, "Introduction to genre-based approach," Jakarta MGMP. http Rev. pucrs. br/ojs/index. php/article/viewfile/93, vol. 61, p. 7023, 2009.

[10] Kementerian Pendidikan dan Kebudayaan, Silabus Mata Pelajaran Bahasa Inggris SMA/MA/SMK/MAK. Jakarta: Ministry of Education and Culture, 2016.

[11] R. Guru, "Tentang Ruang Guru." https://ruangguru.com/general/about (accessed Jul. 25, 2019). 